\title{
Antarctica-Regional Climate and Surface Mass Budget
}

\author{
Vincent Favier $^{1}$ - Gerhard Krinner ${ }^{1}$ - Charles Amory ${ }^{2} \cdot$ Hubert Gallée ${ }^{1}$. \\ Julien Beaumet $^{1}$. Cécile Agosta ${ }^{2}$
}

(C) Springer International Publishing AG 2017

\begin{abstract}
We review recent literature on atmospheric, surface ocean and sea-ice observations and modeling results in the Antarctic sector and relate the observed climatic trends with the potential changes in the surface mass balance (SMB) of the ice sheet since 1900. Estimates of regional scale SMB distribution and trends remain subject to large uncertainties. Approaches combining and comparing multiple satellite and model-based assessments of ice sheet mass balance aim at reducing these knowledge gaps. During the last decades, significant changes in atmospheric circulation occurred around Antarctica, due to the exceptional positive trend in the Southern Annular Mode and to the climate variability observed in the tropical Pacific at the end of the twentieth century. Even though climate over the East Antarctic Ice-Sheet
\end{abstract}

This article is part of the Topical Collection on Glaciology and Climate Change

\author{
Vincent Favier \\ Vincent.favier@univ-grenoble-alpes.fr \\ Gerhard Krinner \\ gerhard.krinner@univ-grenoble-alpes.fr \\ Charles Amory \\ charles.amory@ulg.ac.be \\ Hubert Gallée \\ Hubert.gallee@univ-grenoble-alpes.fr \\ Julien Beaumet \\ Julien.beaumet@univ-grenoble-alpes.fr \\ Cécile Agosta \\ cecile.agosta@ulg.ac.be \\ 1 Institut des Geosciences de l'Environnement UGA/CNRS/IRD/ \\ G-INP, CS 40 700, 38058 Grenoble Cedex 9, France \\ 2 Department of Geography, University of Liege, Liege, Belgium
}

remained quite stable, a warming and precipitation increase was observed over the West Antarctic Ice-Sheet and over the West Antarctic Peninsula (AP) during the twentieth century. However, the high regional climate variability overwhelms climate changes associated to human drivers of global temperature changes, as reflected by a slight recent decadal cooling trend over the AP. Climate models still fail to accurately reproduce the multi-decadal SMB trends at a regional scale, and progress has to be achieved in reproducing atmospheric circulation changes related to complex ocean/ice/atmosphere interactions. Complex processes are also still insufficiently considered, such as (1) specific polar atmospheric processes (clouds, drifting snow, and stable boundary layer physics), (2) surface firn physics involved in the surface drag variations, or in firn air depletion and albedo feedbacks. Finally, progress in reducing the uncertainties relative to projections of the future SMB of Antarctica will largely depend on climate model capability to correctly consider teleconnections with low and mid-latitudes, and on the ability to correct them for biases, taking into account the coupling between ocean, ice, and atmosphere in high southern latitudes.

Keywords Surface mass balance $\cdot$ Antarctica $\cdot$ Climate change $\cdot$ Regional modeling

\section{Introduction}

Antarctic climate and mass balance have been highlighted by the fifth IPCC assessment report (AR5) as one of the main uncertainties both for the climate system [1] and for sea level projections [2]. Consequences of mass balance changes in Antarctica are of global importance, as they directly act on the mean eustatic sea level increase [3], with societal consequences and risks in coastal areas. Recent estimates of mass 
balance variations of Antarctica showed that the ice sheets might become the main contributors to sea-level rise in the coming decades $[4,5]$. In this picture, the surface mass balance (SMB) of Antarctica plays an important role, as it constitutes the only component that may significantly compensate for the future sea level rise [2, 6-10]. Indeed, with a surface area of $12.3 \times 10^{6} \mathrm{~km}^{2}$, the annual SMB of the grounded ice of Antarctica represents a huge mass flux, which is expected to increase in the future.

The SMB (in $\mathrm{kg} \mathrm{m}^{-2} \mathrm{a}^{-1}$ ) at one point is defined as the sum of mass gains and losses at the ice sheet surface:

$$
\mathrm{SMB}=\mathrm{PR}+\mathrm{SU}+\mathrm{TR}+\mathrm{RU}
$$

where PR is total precipitation (solid and liquid), SU is surface sublimation, TR is drifting snow transport (including erosion, deposition, and sublimation of drifting snow particles), and RU is the amount of liquid water from melt and rain that is not retained or refrozen in the snowpack. Fluxes are negative when mass is lost at the surface. Here, we examine variations in regional climate over Antarctica and relate it to potential changes involved in recent and future SMB variations. Finally, we present the ways forward to improve the accuracy of the SMB estimates and forecasts.

\section{Regional Climate}

\section{Recent Trends}

The recent regional climatic trends and variability in Antarctica have been related to atmospheric circulation changes over the Southern Hemisphere [11]. These changes have been associated with the strengthening of the Southern Annular Mode (SAM) and with remote sources of climate variability in particular in the tropical Pacific region (e.g., the ENSO [12-14], the Interdecadal Pacific Oscillation (IPO) $[15,16])$. These atmospheric circulation changes [14, 17] had large effects on the surface ocean circulation [18], on sea ice concentration and extent [13], on ocean stratification [19], and on basal ice-shelf melting [20-22]. However, strong internal climate variability $[11,13,14,23]$ overwhelmed the influence of observed forcings. An exception is the positive trend in the Southern Annular Mode [11], the multiannual mean of which recently reached its most positive phase over the last millennium [24], as a consequence of hemisphericscale stratospheric ozone depletion and of increases in greenhouse gas concentrations [24, 25].

Regional atmospheric changes were largely associated with the SAM and with variability sources in the tropics, both being partly linked [26], with impact particularly over the west Antarctic Ice Sheet (AIS) $[11,27]$. The increasing SAM index resulted in a southward shift of the mid-latitude westerly winds in the southern Indian Ocean [17], along the Antarctic Peninsula (AP) [14, 28] and over west Antarctica [12, 27]. This led to a greater flow of mild, north-westerly air associated to a surface warming through west Antarctica [27]. Onto the AP, this was associated with a significant warming during the second half of the twentieth century, which was amplified on the north-eastern side by a foehn effect [28], but which has slowed markedly in the past 10-15 years [14], changes being largely related to internal climate variability. Associated with changes caused by the SAM in the westerlies, higher sea surface temperatures (SST) in the central tropical Pacific (El Niño and positive IPO situation) were also described as source of enhanced atmospheric Rossby wave trains [14, 29], leading to higher onshore winds (warm advection) over West Antarctica (for instance to Marie Byrd Land) [27]. A strong surface air warming was thus observed over the West AIS $\left(2.18 \pm 1.25^{\circ} \mathrm{C}\right.$ increase during 1958-2010 at Byrd Station $[27,30])$, while East Antarctica did not exhibit any significant trend as a whole [31].

The enhancement of westerly winds led to more northward Ekman transport of cold sub-Antarctic surface waters, leading to sea surface cooling and a subsurface warming of the ocean $[11,13,32]$ except in the Weddell, Bellingshausen, and Amundsen Seas and in the southeast Indian Ocean sector [33]. More precisely, a large expansion of the sea ice extent occurred in the Ross Sea sector as part of a 100-year trend with the highest absolute values occurring at the end of the twentieth century [34]. This was partly compensated by large reductions in the Amundsen-Bellingshausen seas, around the Antarctic Peninsula and in the southeast Indian Ocean [11]. The recent sea ice decline in the Bellingshausen Sea is also unusual in the context of the past $\sim 100$ years [35, 36]. Over 1979-2013, the annual mean total Antarctic sea ice extent increased at a rate of $195 \times 10^{3} \mathrm{~km}^{2}$ per decade [13]. The signal is dominated by the trend over the Ross Sea $\left(119 \times 10^{3} \mathrm{~km}^{2}\right.$ per decade) that is strong but still largely within the bounds of natural variability. Although it is tightly associated to observed atmospheric circulation changes, the sea-ice expansion was also attributed to increased meltwater input caused by glacier wastage, which has contributed to freshening of the Southern Ocean and stabilization of the water column and less vertical ocean heat flux [37-39]. In any case, changes in the sea ice extent are within the internal variability, and an analysis of CMIP5 coupled model outputs [40] suggests that ozone depletion was not the driver of a positive Antarctic sea-ice trend.

Atmospheric changes and sea ice concentration variations are mutually dependent and frequently associated with changes in the tropical Pacific. For instance, Meehl et al. [16] suggested that the IPO can dominate regional atmospheric circulation and sea-ice trends in the Antarctic region at the decadal timescale. Changes in sea 
ice extent are crucial for SMB of Antarctica because more open water leads to enhanced evaporation and moisture availability in the atmospheric column [8, 41]. As an example, the changes in sea level pressure in the Amundsen Sea region enhanced the meridional transport of moist air to the coast of Ellsworth Land (West Antarctica), leading to increased snow accumulation in this region [12], whereas colder airflow was observed offshore in the Ross Sea sector. A detailed account of atmospheric circulation changes in the Amundsen Sea area and their impact on Antarctic climate can be found in Raphael et al. [42].

Nevertheless, the warming and the moisture flux variability cannot be fully explained by either SAM or ENSO, even in the pacific sector at the Gomez site and along the coast of West Antarctica [12, 14], because particular regional settings may overwhelm the large-scale teleconnections with the tropical Pacific. For instance, Li et al. [43] demonstrated that a surface warming in the north and tropical Atlantic Ocean related to the Atlantic Multidecadal Oscillation can contribute to the observed deepening of the Amundsen Sea Low and to the seaice redistribution between the Ross and AmundsenBellingshausen-Weddell seas and to the warming in the AP region. Another example is the enhancement of the climatological trough in the Drake Passage during the 1999-2014 period, which led to greater frequency of cold, east-tosoutheasterly winds and more cyclonic conditions in the northern Weddell Sea. These circulation changes have increased the advection of sea ice towards the east coast of the AP [13]. As a consequence, recent cooling in the AP occurred during the global warming hiatus but was demonstrated to have been driven by local regional climate variability [13, 14] rather than having been associated with the drivers of global temperature change.

Large changes actually reflect the extreme natural internal variability of the regional atmospheric circulation in Antarctica. The significant trends in annual mean sea-ice extent, surface temperature, and sea-level pressure are not unusual when compared with Antarctic palaeoclimate records of the past two centuries [11] and did not exceed the natural variability, except for the SAM [24]. For instance, in spite of the increase of sea ice extent during the last decades, there are indications of higher sea ice extents during the 1960s [44, 45] than during the satellite period after 1979. Even the large warming in west Antarctica is inside the range of natural variability as demonstrated by the strong warming of the 1940s associated with the major 1939-1942 El Niño event [46]. Although ice-core records suggest that recent decades may probably be the warmest in the past 200 years [47], these changes have to be compared to the amplitude of centennialscale Antarctic temperature variations (of up to $2 \mathrm{~K}$ ) associated to the internal mode of southern ocean deep convection variability [23].

\section{Antarctic Climate Change Detection and Attribution, and Projections}

The strong natural variability of Antarctic climate leads to a relatively late projected emergence of an anthropogenic climate change signal over the Antarctic continent [11, 48], not before the mid of the twenty-first century. Therefore, except for specific regional aspects discussed above, there is not much recent scientific literature on climate change detection and attribution studies for the Antarctic as a whole.

Projections of Antarctic climate in recent literature largely rely on outputs from coupled climate models produced in past CMIP exercises, using these output either directly $[8,49-51]$ or as boundary conditions for regional or global variableresolution atmospheric models [41, 52]. However, progresses in the representation of the Antarctic climate in global climate models due to improved representation of physical parameterizations, notably linked to clouds and surface processes, have also been reported recently [8]. Because the principal global effect of Antarctic climate change resides in its impact on global eustatic sea level via the mass balance of the ice sheet, most of these studies focus on future SMB changes. Recent progress in this domain is summarized in the following.

\section{Surface Mass Balance}

\section{SMB Observation}

An accurate assessment of the SMB of Antarctica is particularly difficult [53-55] because reliable field data of SMB [56] and of snow physical and chemical characteristics at high spatial resolution [57] remain very scarce. This is particularly true in low-elevation regions (below $\sim 2000 \mathrm{~m}$ above sea level $[56,58])$, where surveys are complicated by harsh climatic conditions and remoteness from manned stations, whereas this is where SMB is highest and most variable both in time and space [53]. This is also where most of the future SMB change $(60 \%)$ is expected to occur $[6,59]$. The lack of field data is also critical in the vicinity of "wind-glaze" areas (areas subject to strong wind-driven ablation) and in the mega-dunes, which cover together approximately $20 \%$ of the East AIS [60]. Moreover, the difficulty to extract a robust climate variability signal and annually resolved SMB values from single-point measurements and ice cores is particularly high, because climatic signal generally hardly emerges from background noise and variability [61]. Erosion and transport of surface snow layer by strong katabatic winds may produce a mixing between snow layers, and averaging information from multiple sites, providing a good spatial coverage, is generally necessary to retrieve accurate accumulation values [62].

Estimates of the current SMB mean value and trend have been produced at the scale of the continent using a 
combination of satellite gravimetry and altimetry and climate modeling approaches $[3,63,64]$ or using climate modeling alone $[6,9,55,65]$. Interpolation of ground-based measurements at a continental scale suffers primarily from the scarcity of field measurements $[56,66]$, but also to limitations in interpolation techniques. These techniques mainly rely on microwave remote sensing signatures which are altered in lowelevation area due to steep slopes, high surface roughness, melting, and where wind scour provokes the removal of snow layers [67-69]. Indeed, these surface processes (1) alter the signal stored in firn and (2) induce interferences for remote sensing estimates of surface characteristics.

Accumulation radar (e.g., at $100-400 \mathrm{MHz}$ frequency) may be a promising technique to improve the coverage of SMB field measurements over the AIS. Ground penetrating radar (GPR) data allows to retrieve the regional spatial distribution of the SMB [70, 71], although this technique offers information only along traverses. Associated with space- and airborne microwave radar (e.g., between 4 and $6 \mathrm{GHz}$ ) they may offer SMB and firn compaction data at large spatial scale $[72,73]$, as for instance over catchments along the Amundsen Sea Coast of West Antarctica. Nevertheless, the accuracy of GPR approaches relies on a depth-age calibration made on ice cores drilled along radar transects, and inferred from the identification of seasonal cycles [74] or of reference horizons in numerous chemical species and water stable isotopes [71]. However, accurate ice core dating generally relies on betaradioactivity counting and gamma spectrometry, or on identification of well-dated volcanic eruption deposits [54, 62]. Moreover, GPRs are frequently used, but they provide longterm accumulation means, which may differ from recent accumulation values, and they do not give information on annual or decadal variability. Consequently, new measurement techniques are still needed. Radar altimetry ( $\mathrm{C}$ band) appears to qualify as a proxy for precipitation (or long-term mean net $\mathrm{SMB}$ ) in the dry snow zone of the AIS, but the signal is also influenced by other parameters such as surface temperature cycles/anomalies within the firn [75].

Improving the accuracy of regional scale SMB distribution and trend remains a priority, particularly at low elevations [56, 58]. Future progress is contingent on the development of new measurement techniques and on inter-comparison exercises to reconcile satellite measurements and modeling approaches of ice sheet mass balance. The ongoing IMBIE2 project [76] is a follow-up to previous successful efforts in that direction [3].

\section{Observation of Processes Impacting the Regional SMB}

Understanding the complex mechanisms shaping SMB patterns at different time and spatial scales is among the most important challenges in polar climate science [77]. Due to the scarcity of accurate SMB estimates, important efforts have been carried out to quantify the different processes impacting the SMB value. In Antarctica, where surface runoff remains a marginal process [78], the spatial and temporal variability in SMB can mainly be attributed to snowfall and snowdrift processes. Combined approaches using field measurements and model results have revealed that precipitation-driven accumulation can be greatly reduced due to drifting snow erosion [79, $80]$ and that drifting snow sublimation can also contribute significantly to the surface mass loss, particularly where strong katabatic winds prevail $[81,82]$.

While visual observations of drifting snow and direct precipitation measurements are limited by the inability to distinguish between actual snowfall and drifting snow particles originating from the ground, efforts have gone in the recent years into obtaining reliable estimates of solid precipitation amounts. For instance, CloudSat products offer unprecedented capability to quantitatively assess Antarctic precipitation statistics and rates at $\sim 1 \mathrm{~km}$ above the surface [83] and provide an independent assessment to other widely used observation-based and reanalysis products for intercomparison of high-latitude precipitation characteristics [84].

Ground-based techniques to assess the evolution of clouds and precipitating systems have also been developed using a ceilometer, an infrared pyrometer and a vertically profiling precipitation radar [85]. This set of instruments gives information on cloud properties (ice, liquid-containing clouds and precipitating clouds, vertical extent) and also enables to characterize how clouds affect the surface radiative fluxes. More recently, a precipitation monitoring campaign using a different combination of instruments (including a polarimetric weather radar, a micro rain radar, a weighing gauge, and a multi-angle snowflake camera) has given information on hydrometeor types and provided the first model-free estimates of precipitation in Antarctica [86].

Remote sensing techniques developed for monitoring clouds and aerosols from space have also been applied to the detection of drifting snow properties including spatial and temporal frequency, layer height, and optical depth of drifting snow events [87]. Nonetheless, although satellites provide a large spatial coverage, quantitative estimates remain limited by the vertical resolution of signal close to the surface $(\sim 20 \mathrm{~m})$, by the sensitivity to the occurrence of clouds and by their dependency on re-analysis data (wind speed, temperature, and low-level moisture) for mass fluxes calculations [88].

Drifting snow has been studied from field measurements, but the few data collected are only available within the surface layer $(<10 \mathrm{~m})$. An important focus has been made on the drifting snow flux using different generations of acoustic FlowCapt ${ }^{\mathrm{TM}}$ devices [89], which were proved to be well suited for remote locations and long-term monitoring under harsh conditions. However, it was demonstrated that the firstgeneration of FlowCapt ${ }^{\mathrm{TM}}$ gives significant errors in drifting snow flux estimations which prevent the use of such measurements for research purposes [90]. Nevertheless, these original 
devices were used for observations [91] and satellite data evaluation [87] and for model evaluation [92]. As a consequence, quantitative aspects in these studies should be considered with caution. The second-generation FlowCapt ${ }^{\mathrm{TM}}$ device was shown to slightly underestimate the actual flux when compared to a reference optical sensor (SPC-S7; [93]). This device should be used instead [94]. The second-generation FlowCapt ${ }^{\mathrm{TM}}$ sensors have been installed in a coastal location of Adélie Land [95] and are operating continuously since February of 2010, giving long-term dataset of ground-based drifting snow measurements in Antarctica, which may be used to evaluate and complement satellite data and modeling results.

\section{Modeling Aspects}

The geographical patterns of the modeled Surface Energy Balance (SEB) and subsequent SMB highly depend on the model resolution $[6,9,96,97]$ and on the inclusion of several key physical processes (Fig. 1). For instance, clouds microphysics with parameterizations for ice cloud supersaturation acts on changes in large-scale circulation patterns and alter topographically forced precipitation [78, 98]. But clouds also act as short wave radiation filters and longwave radiation emitters, influencing the both the atmosphere and surface heat budgets [8].

Accounting for the drifting snow flux in modeling studies has demonstrated that this process has an important impact on the regional SMB patterns [99]; however, its representation in climate models is still poorly validated [100]. Lenaerts and van den Broeke [99] computed that sublimation of blown snow particles removes $\sim 6 \%$ of the precipitation, considering the whole ice sheet. Its impact on the regional SEB [98] or on the accurate representation of air moisture with important feedback on surface sublimation has also been demonstrated [101]. However, no reliable quantitative estimation of the amount of snow transported by the wind exists beyond a few meters above the ground, even if occurrence of drifting snow has been observed [87]. Model hardly simulates the drifting snow mass transport close to the surface, and values differ by more than one order of magnitude with field observations [100, 102]. Moreover, the relative importance of the physical processes influencing drifting snow transport has to be quantified [103]. This concerns the increase of surface snow density, the cooling of near-surface air through sublimation of the drifting snow, the stabilization of turbulence, or the increase of the downslope pressure gradient force in the katabatic flow.

Thanks to recent observational studies, the understanding of the physical processes controlling (1) the surface turbulent energy and mass fluxes and (2) the evolution of surface snow properties has been improved. Studies demonstrated the need to develop new parameterizations of the surface momentum and sensible heat fluxes in very stable conditions [104], whereas interactions between erosion and surface drag over sastrugi-covered areas $[105,106]$ should be considered. The dynamic representation of the roughness length is necessary to accurately represent the seasonal variations of the surface wind stress, of the related drifting snow, and ultimately of the SMB in windy regions [105, 106]. An analysis at decametre scales using a stochastic snow redistribution scheme also demonstrated that snow drift processes are crucial at very fine spatial scale and are necessary to retrieve (1) the statistics of annual ablation occurrences over mean positive accumulation sites and (2) the vertical profiles of snow density and specific surface area down to $50 \mathrm{~cm}$ depth [107].

Finally, an important focus has been made on surface processes involved in ice-shelves destabilization through hydrofracturing. Attention has been paid to the assessment of the SEB [108], surface melt, and subsequent firn air depletion over ice shelves [109]. Consequences of subsurface refreezing melt ponds for ice formation and ice-shelf structure [110] have been explored. Firn models have been improved to account for compaction rates and for meltwater hydrology $[111,112]$. In particular, these approaches demonstrated that surface winds are crucial to enhance melting over ice-shelves in the Antarctic Peninsula [113, 114] but also in East Antarctica [115], where meltwater-induced firn air depletion is found in the grounding zone and can ultimately lead to the disintegration of ice shelves.

\section{Mean SMB and Trend}

\section{Mean Value}

According to previous references, the current SMB of the Antarctic grounded ice-sheet was assumed to range between $1768 \mathrm{Gt} \mathrm{a}^{-1}$ [66] and $1983 \mathrm{Gt} \mathrm{a}^{-1}$ [55], even though more recent model estimates suggest that the actual value may be slightly higher [6, 8, 9, 78]. However, Scambos et al. [60] concluded that current estimate of the SMB over East Antarctica might be overestimated by $46-82 \mathrm{Gt} \mathrm{a}^{-1}$ due to inaccurate estimations over the "wind-glaze" areas. Das et al. [79] also estimated that 2.7-6.6\% of the surface area of Antarctica presents a negative net accumulation due to wind scour and that the snow mass input is overestimated by $11-$ 36.5 $\mathrm{Gt} \mathrm{a}^{-1}$ in present SMB calculations. More generally, it has been argued that the largest uncertainty in SMB estimates from regional climate models in East Antarctica is localized in regions where the wind scour impacts on both ablation and redeposition areas [81].

\section{Recent Trends}

Over the twentieth century, SMB variations were weak over Antarctica [8]. However, several areas presented a significant SMB increase as for instance on the West AIS, where a $30 \%$ 
Fig. 1 a Key large-scale teleconnections and regional processes impacting the SMB and requiring a better representation in global circulation models. Background map is SMB from [6]. Also presented are the main regions discussed in the text and the main processes impacting the regional SMB over the plateau, in the coastal region, and over ice shelves (in yellow). b Schematic presentation of the main physical processes requiring a better representation in regional circulation models a Teleconnections and key processes impacting the SMB

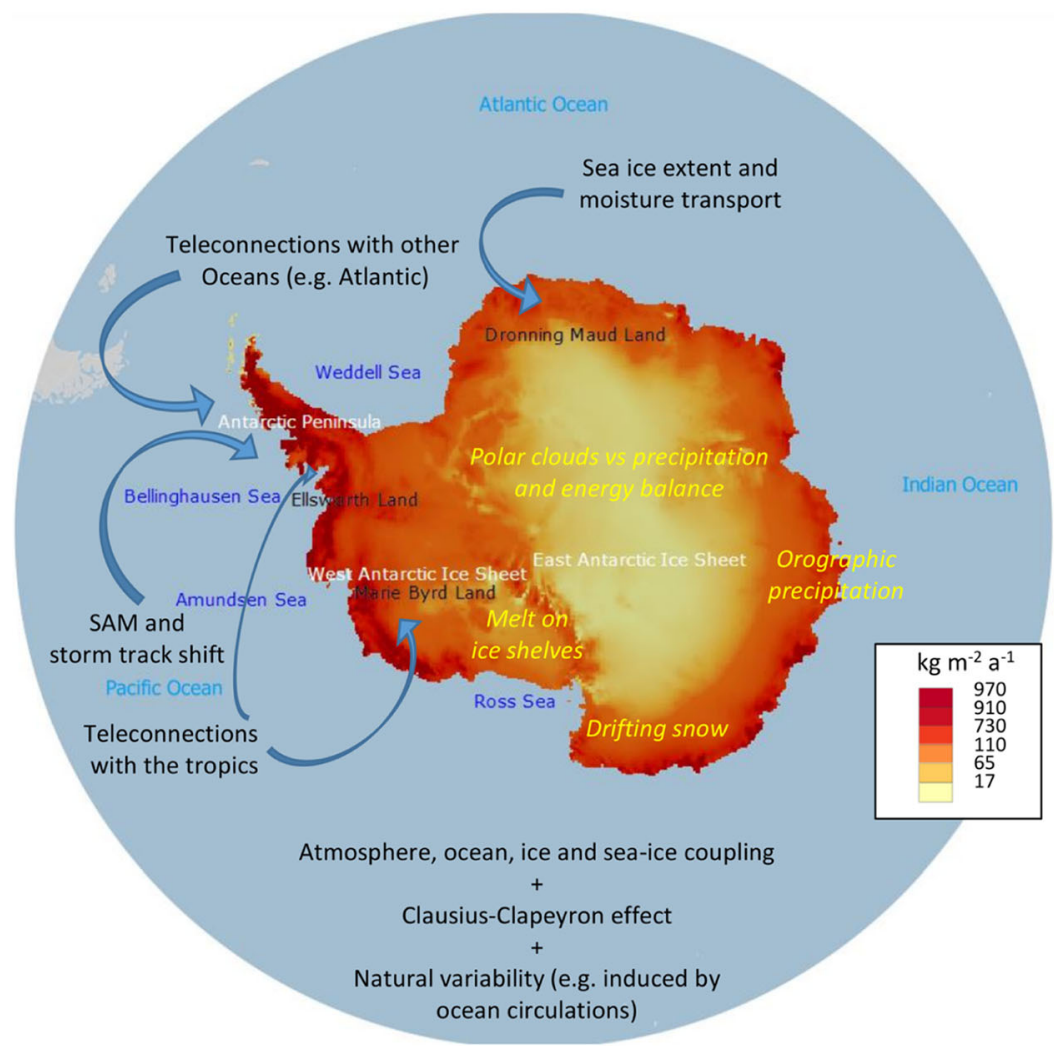

b Key regional scale and surface processes

\begin{tabular}{|c|c|c|c|}
\hline Region & Plateau & Coastal region & Ice shelves \\
\hline & \multicolumn{3}{|c|}{ Polar clouds $\Leftrightarrow$ precipitation and energy balance } \\
\hline Precipitation & $\begin{array}{l}\text { Cloud microphysics } \\
\text { (clear sky vs. synoptically } \\
\text { caused precipitation) }\end{array}$ & $\begin{array}{l}\text { Model resolution } \\
\text { (orographic } \\
\text { precipitation) }\end{array}$ & $\begin{array}{l}\text { Coupling with } \\
\text { sea-ice and oceans }\end{array}$ \\
\hline $\begin{array}{l}\text { Surface } \\
\text { processes }\end{array}$ & $\begin{array}{l}\text { Stable boundary layer } \\
\text { (vertical resolution) }\end{array}$ & $\begin{array}{l}\text { Drifting snow } \\
\text { osion / deposition }\end{array}$ & \\
\hline \multirow{2}{*}{$\begin{array}{l}\text { Snow } \\
\text { model }\end{array}$} & \multicolumn{3}{|c|}{ Grain size and albedo } \\
\hline & $\begin{array}{c}\text { Erodability vs. sintering, } \\
\text { Densification }\end{array}$ & $\begin{array}{r}\text { Mel } \\
\text { Percolatic } \\
\text { Ponds a }\end{array}$ & $\begin{array}{l}\text { 3/refreezing } \\
\text { lepletion } \\
\text { s. lateral transfer } \\
\text { hydrofracturing }\end{array}$ \\
\hline
\end{tabular}

increase was observed at various sites in Ellsworth Land [12, 116] or in the Dronning Maud Land [117]. It has been suggested that overall, SMB increased across the grounded AIS of $160 \pm 20 \mathrm{Gt} \mathrm{a}^{-1}(\sim 9 \%)$ since $1800 \mathrm{AD}$ and $110 \pm 22 \mathrm{Gt} \mathrm{a}^{-1}$ ( 6\%) since 1900 (1900-2010), with the largest (area weighted) contribution from the West AP [58], where a doubling of accumulation since 1850 has been identified [118]. An SMB increase has also been suggested over the whole AP over the last 50 years $[116,119]$. Nevertheless, changes observed in the
SMB since the 1960s mainly appeared at low elevations (coastal regions) with an increase of about $10 \%$. In addition, even though ice-core accumulation records should be interpreted cautiously over the highest part of the East Antarctic ice divide [58] because of low accumulation rates and strong impacts of post-deposition processes, the data suggest that current SMB in this region is not exceptionally high compared to the last 800 years [77]. Finally, changes are very variable in space and time. For instance, at short time scales, 
precipitation may have decreased over 2003-2013 for both AP and West AIS, whereas precipitation may have increased on East AIS [63].

Even though the interannual variability of accumulation is partially resolved by models at a regional scale in Adelie Land [53], in the Antarctic Peninsula [97], and in Dronning Maud Land $[117,120]$, there is still no proof in either observations or regional climate simulations that accumulation increased in Antarctica as a whole [8]. In particular, modeled inverse relationship between sea-ice extent and the SMB of Antarctica [8, 51] demonstrates that recent inter-decadal changes are hard to explain and model. For instance, models do not represent any significant trends in the AP over the last 36 years, except for snowmelt that shows a significant decrease [97].

\section{Future Changes}

According to regional circulation modeling using SRES A1B scenario, the future increase of snow accumulation in Antarctica (Table 1) at the end of the twenty-first century (15\%) will represent a compensation of about $-5 \mathrm{~cm}$ to the future sea level rise ($15 \mathrm{~cm}$ in 2200 [6, 120]). Estimates have been given for the RCPs scenarios but for CMIP5 models. Previous estimates given for SRES A1B should be almost reached under RCP2.6 scenario, whereas the sea level rise mitigation by precipitation increase under RCP8.5 scenario may reach -71 to $-79 \mathrm{~mm}$ SLR (sea level rise) by the year 2100 [50, 51]. Attention in regional modeling has been paid in assessing future melting amounts in Antarctica, with a focus on ice shelf melting [52], but future SMB changes under RCPs scenarios are still not available using regional circulation models, while simulated precipitation increase strongly depends on model resolution $[6,8,41,49]$. Morever, the modeled increase will be mainly due to the variation in air moisture resulting from warming (Clausius-Clapeyron equation, see the scaling factors given for every model in Table 1), and through the characteristics and frequency of Antarctic clouds. However, the increase driven by stronger meridional winds is still limited in large-scale and regional-scale modeling approaches $[8,121]$, and changes induced by Antarctic sea-ice cover variations are still poorly modeled in state-of-the-art coupled climate models [122].

\section{Ways Forward}

Already, the earliest coupled model projections of transient anthropogenic climate change $[123,124]$ predicted a slow emergence of a significant warming signal in the high southern latitudes because of the presence of the Southern Ocean $[11,125]$. This is combined with strong natural climate variability in the polar regions [14]. The clearest and, in terms of global consequences, most alarming signs of ongoing persistent changes in the Antarctic climate system are therefore linked to ice sheet-ocean interactions (see the review from Pattyn et al. [126], this issue), which are beyond the scope of this review. Antarctic climate change and consequent changes of the Antarctic SMB are strongly conditioned by the evolution of the Southern Ocean $[8,41]$; moreover, SMB changes will be strongest, and the processes are arguably the most complicated, in the coastal regions. This allows identifying conditions and possibilities for efficient future progress
Table 1 Summary of future SMB changes in Antarctica

\begin{tabular}{|c|c|c|c|c|c|}
\hline & Model & A1B & $\mathrm{RCP} 2.6$ & RCP8.5 & All RCPs \\
\hline \multirow[t]{6}{*}{ Scaling coefficient ${ }^{\mathrm{a}}$} & LMDZ4 & $4.8-6.3[41]$ & & & \\
\hline & RACMO2 & $\begin{array}{l}5.1[6] \\
4.8-5.5[9]\end{array}$ & & & \\
\hline & SMHiL & $5.6[6]$ & & & \\
\hline & All CMIP5 & & & & $6.1[49]$ \\
\hline & & & & & $7.4^{\mathrm{b}}[51]$ \\
\hline & CESM & & $5.2[8]$ & $3.8[8]$ & \\
\hline \multirow[t]{7}{*}{ SMB change } & LMDZ4 & $13 \%[6]$ & & & \\
\hline & RACMO2 & $15 \%[9]$ & & & \\
\hline & SMHiL & $16 \%[6]$ & & & \\
\hline & CESM & & $9 \%[8]$ & $18 \%[8]$ & \\
\hline & All CMIP5 & & $5.5 \%^{\mathrm{b}}[51]$ & $24.5 \%^{\mathrm{b}}[51]$ & \\
\hline & & & $-19 \mathrm{~mm} \mathrm{SLR}^{\mathrm{c}}[51]$ & $-71 \mathrm{~mm} \mathrm{SLR}{ }^{\mathrm{c}}[51]$ & \\
\hline & & & & $-79 \mathrm{~mm} \mathrm{SLR}{ }^{\mathrm{c}}[50]$ & \\
\hline
\end{tabular}

${ }^{\mathrm{a}} \mathrm{In} \% \mathrm{~K}^{-1}$

${ }^{\mathrm{b}}$ Increase in precipitation only

${ }^{\mathrm{c}}$ Accumulated sea level rise compensation by the year 2100 (relative to 1986-2005) 
in the understanding and prediction of the Antarctic climate and SMB. Improvements of models are also of interest for assessment of short-term risks and safety management in the polar regions through weather and sea-ice conditions forecasts [127]. The intensive observation and modeling activities planned in the framework of the YOPP ${ }^{1}$ (Year of Polar Prediction) program is an opportunity to understand particular events such as the Antarctic sea ice minimum extent observed in April 2017.

Many physical processes relevant for Antarctic nearsurface climate and SMB are still only insufficiently well understood (Fig. 1). Concerning the near-surface climate, the dominant occurrence of a stable atmospheric boundary layer is certainly one of the most characteristic elements of the Antarctic climate system. Despite long-standing efforts, the representation of turbulent fluxes of momentum and heat in stably stratified boundary layers in global and regional climate models and reanalyses [128] is still not satisfying. The GEWEX/WCRP Atmospheric Boundary Layer Study Phase $4\left(\mathrm{GABLS}^{2}\right)$, an initiative that focuses on test cases at Dome $\mathrm{C}$ on the East Antarctic Plateau, is an opportunity for both improved process understanding and rapid transposition of this improved understanding into global and regional climate models.

In the future, increasingly large parts of the coastal Antarctic will probably be characterized by higher snow melt rates [52]. Associated complex processes like meltwater refreezing in the snowpack and meltwater drainage [129] need to be well represented in climate models in order to correctly simulate the ice sheet SMB. Improving the representation of snow, including Antarctic snow, in current-generation climate models is the aim of the Earth System Model Snow module Intercomparison Project (ESM-SnowMIP ${ }^{3}$ ) under the auspices of the WCRP Grand Challenge "Melting Ice \& Global Consequences" that will include case studies at Dome C and potentially over Antarctic shelf areas. Further progress is also required in the representation of blowing snow or, at least, in a better quantification of its impact of the ice sheet SMB. A further international initiative worth noting here is ISMIP6 $6^{4}$, a CMIP6 sub-project that aims to make progress in coupling ice sheet models and Earth system models; evaluating the ice sheet SMB simulated by the CMIP6 Earth system models is part of the ISMIP6 effort.

Large knowledge gaps concern the properties, role, and evolution of tropospheric clouds in Antarctica and their representation in climate models [130]. Recent important progress has been reported on the representation of cloud liquid and ice water path at high latitudes by CloudSat-Calipso due to an

\footnotetext{
${ }_{1}^{1} \mathrm{http}: / /$ www.polarprediction.net/yopp/

2 http://www.umr-cnrm.fr/aladin/meshtml/GABLS4/GABLS4.html

${ }^{3} \mathrm{http}: / /$ www.climate-cryosphere.org/activities/targeted/esm-snowmip

${ }^{4} \mathrm{http}: / /$ www.climate-cryosphere.org/activities/targeted/ismip6
}

explicit determination of cloud phase [131]. Ground-based observatories combining sets of instruments used synergetically to study the evolution of clouds and precipitating systems [85, 86] have been identified as an important condition for progress in understanding and quantifying tropospheric Antarctic clouds. For the study of Antarctic clouds and precipitation, the combination of these ground-based studies with improved large-scale satellite observations [83] now paves the ground for a better evaluation of these aspects in climate models [51, 131]; similarly, it is this combination of small-scale process studies with large-scale observations that will also lead to improved parameterizations in climate models.

The need for high spatial resolution, both horizontal [97] and vertical [132], is frequently emphasized in studies of the Antarctic climate and SMB. Interestingly, substantial horizontal climate gradients over short distances do seem to occur also in the absence of steep topography, for example across Dome C [133]. This clearly suggests that projections of the Antarctic climate, and more specifically of the Antarctic SMB, will, in the foreseeable future, continue to require statistical or dynamical downscaling. In this respect, the classical "garbage ingarbage out" problem of climate projections at the regional scale [134] naturally also applies to Antarctica, and it is probably particularly acute in this region given typically substantial errors of global coupled climate models in the Antarctic [125]. Dynamical regional downscaling of climate change projections such as planned in the CORDEX exercise [135, 136], which consists of using coupled climate model output to drive regional climate models, might suffer from this drawback. Selection of the driving global coupled model [137], based on the coupled models' ability to correctly represent essential regional circulation features, is a frequently used procedure to putatively circumvent or at least alleviate this "garbage in-garbage out" problem. This will also certainly be a condition for useful downscaling of coupled model climate projections in the Antarctic CORDEX initiative. ${ }^{5}$ An attractive alternative, or intermediate step, could be to produce intermediate atmosphere-only global climate simulations using de-biased sea-surface conditions based on present-day observations and oceanic climate change signals from coupled climate models [41, 138]; these de-biased intermediate global simulations could then be used to drive a regional climate model. However, given that this approach does not correct for (at least currently) inevitable errors of the global atmospheric model used in the intermediate step, a further improvement could be to de-bias the global atmospheric model simulations at runtime $[139,140]$. If it can be shown that climate model biases are at least to a large degree stationary, that is, similar in different climatic conditions, such an intermediate step between the coupled climate model and a high-resolution regional climate model could provide improved boundary

\footnotetext{
${ }^{5} \mathrm{http} / / /$ www.climate-cryosphere.org/activities/targeted/polar-cordex/antarctic
} 
conditions for the high-resolution regional climate model simulations required for useful projections of Antarctic climate and SMB changes.

In any case, the coastal regions of Antarctica will likely be subject to important atmospheric circulation changes resulting from a competition between local and remote forcings. Changes resulting from variations in the pressure gradient existing between the mid and the high latitudes (the Southern Annular Mode-SAM [25]) will interact with those occurring in particular in the Tropics [141]. During the last 50 years, the SAM presented an increasing trend and reached its highest values over the last millennium [24]. This resulted in a shift of the storm track in particular in the Southern Indian Ocean [17]. Important changes in the wind regimes and strength $[14,28,142]$ were observed, resulting in an important accumulation increase in West Antarctica and along the western side of the Peninsula (e.g., a 30\% increase at various sites has been observed since 1900 [12]). This increased SMB should progressively be phased out due to ozone recovery, which is projected to have the opposite effect on the SAM than the ongoing increase of the concentrations of other major greenhouse gases [121]. However, the advection of warm, moist air into West Antarctica and the AP will also largely depend on the behavior of the ENSO [141], characterized by an increased frequency of the El Niño-La Niña extreme events $[143,144]$ transmitted to Antarctica via the South Pacific. Correctly projecting these global-scale circulation changes and their impacts on the Antarctic circulation patterns and SMB is a major challenge for global climate models; currently, there are few reasons to believe that they are correctly modeled. In this context, more detailed investigations of possible teleconnections involving surrounding Southern Ocean regions other than the Pacific sector [11, 14, 23, 43, 58, 117] could be a worthy undertaking.

Finally, the sea ice extent is a general deficiency of state-ofthe-art coupled climate models and a potential source for inaccuracies in the assessment of future changes of accumulation over the ice sheet. Improving our capability to correctly simulate the Antarctic sea ice changes and zonal atmospheric pressure response to anthropogenic climate change and the resulting poleward heat and moisture advections is thus within the main priorities in Antarctica. This will rely on better coupling between ocean, ice, and atmosphere in high southern latitudes (see reviews from Asay-Davis et al., this issue, and Pattyn et al. [126], this issue).

Acknowledgments The authors acknowledge the support from Agence Nationale de la Recherche scientific for the scientific traverses in Antarctica and the associated research on climate and surface mass balance (projects ANR-14-CE01-0001 (ASUMA) and ANR-16-CE01-0011 (EAIIST)), and the support from Institut Paul-Emile Victor (IPEV) for the surface mass balance observatory in Antarctica (GLACIOCLIMSAMBA). We also thank the two anonymous reviewers for their relevant comments.

\section{Compliance with Ethical Standards}

Conflict of Interest On behalf of all authors, the corresponding author states that there is no conflict of interest.

\section{References}

1. Bindoff NL, Stott PA, AchutaRao KM, Allen MR, Gillett N, Gutzler D, et al. Detection and attribution of climate change: from global to regional. In: Stocker TF, Qin D, Plattner G-K, Tignor M, Allen SK, Boschung J, Nauels A, Xia Y, Bex V, Midgley PM, editors. Climate Change 2013: The Physical Science Basis. Contribution of Working Group I to the Fifth Assessment Report of the Intergovernmental Panel on Climate Change. Cambridge: Cambridge University Press; 2013.

2. Church JA, Clark PU, Cazenave A, Gregory JM, Jevrejeva S, Levermann A, et al. Sea Level Change. In: Stocker TF, Qin D, Plattner G-K, Tignor M, Allen SK, Boschung J, Nauels A, Xia Y, Bex V, Midgley PM, editors. Climate Change 2013: The Physical Science Basis. Contribution of Working Group I to the Fifth Assessment Report of the Intergovernmental Panel on Climate Change. Cambridge: Cambridge University Press; 2013.

3. Shepherd A, Ivins ER, Geruo A, Barletta VR, Bentley MJ, Bettadpur S, et al. A Reconciled Estimate of Ice-Sheet Mass Balance. Science. 2012;338(6111):1183-9.

4. De Conto RM, Pollard D. Contribution of Antarctica to past and future sea-level rise. Nature. 2016;531(7596):591-7.

5. Ritz C, Edwards TL, Durand G, Payne AJ, Peyaud V, Hindmarsh RCA. Potential sea-level rise from Antarctic ice-sheet instability constrained by observations. Nature. 2015;528(7580):115-8. https://doi.org/10.1038/nature16147.

6. Agosta C, Favier V, Krinner G, Gallée H, Fettweis X, Genthon C. High-resolution modelling of the Antarctic surface mass balance, application for the twentieth, twenty first and twenty second centuries. Clim Dyn. 2013;41(11-12):3247-60.

7. Krinner G, Magand O, Simmonds I, Genthon C, Dufresne J-L. Simulated Antarctic precipitation and surface mass balance at the end of the twentieth and twenty-first centuries. Clim Dyn. 2006;28(2-3):215-30.

8. Lenaerts JTM, Vizcaino M, Fyke J, van Kampenhout L, van den Broeke MR. Present-day and future Antarctic ice sheet climate and surface mass balance in the Community Earth System Model. Clim Dyn. 2016;47(5-6):1367-81.

9. Ligtenberg SRM, van de Berg WJ, van den Broeke MR, Rae JGL, van Meijgaard E. Future surface mass balance of the Antarctic ice sheet and its influence on sea level change, simulated by a regional atmospheric climate model. Clim Dyn. 2013;41(3-4):867-84.

10. Wouters B, Bamber JL, van den Broeke MR, Lenaerts JTM, Sasgen I. Limits in detecting acceleration of ice sheet mass loss due to climate variability. Nat Geosci. 2013;6(8):613-6.

11. Jones JM, Gille ST, Goosse H, Abram NJ, Canziani PO, Charman DJ, et al. Assessing recent trends in high-latitude Southern Hemisphere surface climate. Nat Clim Chang. 2016;6(10):917-26.

12. Thomas ER, Hosking JS, Tuckwell RR, Warren RA, Ludlow EC. Twentieth century increase in snowfall in coastal West Antarctica. Geophys Res Lett. 2015;42(21):9387-93.

13. Turner J, Hosking JS, Marshall GJ, Phillips T, Bracegirdle TJ. Antarctic sea ice increase consistent with intrinsic variability of the Amundsen Sea Low. Clim Dyn. 2016;46(7-8):2391-402.

14. Turner J, Lu H, White I, King JC, Phillips T, Hosking JS, et al. Absence of 21st century warming on Antarctic Peninsula consistent with natural variability. Nature. 2016;535(7612):411-5. 
15. Vance TR, Roberts JL, Plummer CT, Kiem AS, van Ommen TD. Interdecadal Pacific variability and eastern Australian megadroughts over the last millennium. Geophys Res Lett. 2015;42(1):129-37.

16. Meehl GA, Arblaster JM, Bitz CM, Chung CTY, Teng H. Antarctic sea-ice expansion between 2000 and 2014 driven by tropical Pacific decadal climate variability. Nat Geosci. 2016;9(8):590-5.

17. Favier V, Verfaillie D, Berthier E, Menegoz M, Jomelli V, Kay JE, et al. Atmospheric drying as the main driver of dramatic glacier wastage in the southern Indian Ocean. Sci Rep. 2016;6(1) https:// doi.org/10.1038/srep32396.

18. Schmidtko S, Heywood KJ, Thompson AF, Aoki S. Multidecadal warming of Antarctic waters. Science. 2014;346(6214):1227-31.

19. Goosse H, Zunz V. Decadal trends in the Antarctic sea ice extent ultimately controlled by ice-ocean feedback. Cryosphere. 2014;8(2):453-70

20. Pritchard HD, Ligtenberg SRM, Fricker HA, Vaughan DG, van den Broeke MR, Padman L. Antarctic ice-sheet loss driven by basal melting of ice shelves. Nature. 2012;484(7395):502-5.

21. Dutrieux P, De Rydt J, Jenkins A, Holland PR, Ha HK, Lee SH, et al. Strong sensitivity of Pine Island ice-shelf melting to climatic variability. Science. 2014;343(6167):174-8.

22. Fogwill CJ, Phipps SJ, Turney CSM, Golledge NR. Sensitivity of the Southern Ocean to enhanced regional Antarctic ice sheet meltwater input. Earths Future. 2015;3(10):317-29.

23. Pedro JB, Martin T, Steig EJ, Jochum M, Park W, Rasmussen SO. Southern Ocean deep convection as a driver of Antarctic warming events. Geophys Res Lett. 2016;43(5):2192-9.

24. Abram NJ, Mulvaney R, Vimeux F, Phipps SJ, Turner J, England MH. Evolution of the Southern Annular Mode during the past millennium. Nat Clim Chang. 2014;4(7):564-9.

25. Thompson DWJ, Solomon S, Kushner PJ, England MH, Grise KM, Karoly DJ. Signatures of the Antarctic ozone hole in Southern Hemisphere surface climate change. Nat Geosci. 2011;4(11):741-9.

26. Ding Q, Steig EJ, Battisti DS, Wallace JM. Influence of the tropics on the Southern Annular Mode. J Clim. 2012;25(18):6330-48.

27. Bromwich DH, Nicolas JP, Monaghan AJ, Lazzara MA, Keller LM, Weidner GA, et al. Central West Antarctica among the most rapidly warming regions on Earth. Nat Geosci. 2012;6(2):139-45.

28. Grosvenor DP, King JC, Choularton TW, Lachlan-Cope T. Downslope föhn winds over the Antarctic Peninsula and their effect on the Larsen ice shelves. Atmospheric Chem Phys. 2014;14(18):9481-509.

29. Turner J. The El Niño-southern oscillation and Antarctica. Int J Climatol. 2004;24(1):1-31.

30. Bromwich DH, Nicolas JP, Monaghan AJ, Lazzara MA, Keller LM, Weidner GA, et al. Corrigendum: Central West Antarctica among the most rapidly warming regions on Earth. Nat Geosci. 2013;7(1):76

31. Nicolas JP, Bromwich DH. New reconstruction of Antarctic nearsurface temperatures: multidecadal trends and reliability of global reanalyses. J Clim. 2014;27(21):8070-93.

32. Raphael MN, Hobbs W. The influence of the large-scale atmospheric circulation on Antarctic sea ice during ice advance and retreat seasons. Geophys Res Lett. 2014;41(14):5037-45.

33. Fan T, Deser C, Schneider DP. Recent Antarctic sea ice trends in the context of Southern Ocean surface climate variations since 1950. Geophys Res Lett. 2014;41(7):2419-26.

34. Thomas ER, Abram NJ. Ice core reconstruction of sea ice change in the Amundsen-Ross Seas since 1702 A.D. Geophys Res Lett. 2016;43(10):5309-17.

35. Porter SE, Parkinson CL, Mosley-Thompson E. Bellingshausen Sea ice extent recorded in an Antarctic Peninsula ice core. J Geophys Res Atmospheres. 2016;121(23):13,886-900.
36. Abram NJ, Thomas ER, McConnell JR, Mulvaney R, Bracegirdle TJ, Sime LC, et al. Ice core evidence for a 20th century decline of sea ice in the Bellingshausen Sea, Antarctica. J Geophys Res. 2010;115(D23) https://doi.org/10.1029/2010JD014644.

37. Bintanja R, van Oldenborgh GJ, Drijfhout SS, Wouters B, Katsman CA. Important role for ocean warming and increased ice-shelf melt in Antarctic sea-ice expansion. Nat Geosci. 2013;6(5):376-9.

38. de Lavergne C, Palter JB, Galbraith ED, Bernardello R, Marinov I. Cessation of deep convection in the open Southern Ocean under anthropogenic climate change. Nat Clim Chang. 2014;4(4):278 82.

39. Swart NC, Fyfe JC. The influence of recent Antarctic ice sheet retreat on simulated sea ice area trends. Geophys Res Lett. 2013;40(16):4328-32.

40. Sigmond M, Fyfe JC. The Antarctic sea ice response to the ozone hole in climate models. J Clim. 2014;27(3):1336-42.

41. Krinner G, Largeron C, Ménégoz M, Agosta C, Brutel-Vuilmet C. Oceanic forcing of Antarctic climate change: a study using a stretched-grid atmospheric general circulation model. J Clim. 2014;27(15):5786-800.

42. Raphael MN, Marshall GJ, Turner J, Fogt RL, Schneider D, Dixon DA, et al. The Amundsen sea low: variability, change, and impact on Antarctic climate. Bull Am Meteorol Soc. 2016;97(1):111-21.

43. Li X, Holland DM, Gerber EP, Yoo C. Impacts of the north and tropical Atlantic Ocean on the Antarctic Peninsula and sea ice. Nature. 2014;505(7484):538-42.

44. Gallaher DW, Campbell GG, Meier WN. Anomalous variability in Antarctic sea ice extents during the 1960s with the use of Nimbus data. IEEE J Sel Top Appl Earth Obs Remote Sens. 2014;7(3): 881-7.

45. Meier WN, Gallaher D, Campbell GG. New estimates of Arctic and Antarctic sea ice extent during September 1964 from recovered Nimbus I satellite imagery. Cryosphere. 2013;7(2):699-705.

46. Schneider DP, Steig EJ. Ice cores record significant 1940s Antarctic warmth related to tropical climate variability. Proc Natl Acad Sci. 2008;105(34):12154-8.

47. Steig EJ, Ding Q, White JWC, Küttel M, Rupper SB, Neumann TA, et al. Recent climate and ice-sheet changes in West Antarctica compared with the past 2,000 years. Nat Geosci. 2013;6(5):372-5.

48. Mora C, Frazier AG, Longman RJ, Dacks RS, Walton MM, Tong EJ, et al. The projected timing of climate departure from recent variability. Nature. 2013;502(7470):183-7.

49. Frieler K, Clark PU, He F, Buizert C, Reese R, Ligtenberg SRM, et al. Consistent evidence of increasing Antarctic accumulation with warming. Nat Clim Chang. 2015;5(4):348-52.

50. Previdi M, Polvani LM. Anthropogenic impact on Antarctic surface mass balance, currently masked by natural variability, to emerge by mid-century. Environ Res Lett. 2016;11(9):094001.

51. Palerme C, Genthon C, Claud C, Kay JE, Wood NB, L'Ecuyer T. Evaluation of current and projected Antarctic precipitation in CMIP5 models. Clim Dyn. 2017;48(1-2):225-39.

52. Trusel LD, Frey KE, Das SB, Karnauskas KB, Kuipers Munneke $P$, van Meijgaard E, et al. Divergent trajectories of Antarctic surface melt under two twenty-first-century climate scenarios. Nat Geosci. 2015;8(12):927-32.

53. Agosta C, Favier V, Genthon C, Gallée H, Krinner G, Lenaerts JTM, et al. A 40-year accumulation dataset for Adelie Land, Antarctica and its application for model validation. Clim Dyn. 2012;38(1-2):75-86.

54. Eisen O, Frezzotti M, Genthon C, Isaksson E, Magand O, van den Broeke MR, et al. Ground-based measurements of spatial and temporal variability of snow accumulation in East Antarctica. Rev Geophys. 2008;46(2):RG2001.

55. Lenaerts JTM, van den Broeke MR, van de Berg WJ, van Meijgaard E, Kuipers Munneke P. A new, high-resolution surface 
mass balance map of Antarctica (1979-2010) based on regional atmospheric climate modeling. Geophys Res Lett. 2012;39(4): L04501.

56. Favier V, Agosta C, Parouty S, Durand G, Delaygue G, Gallée H, et al. An updated and quality controlled surface mass balance dataset for Antarctica. Cryosphere. 2013;7(2):583-97.

57. Masson-Delmotte V, Hou S, Ekaykin A, Jouzel J, Aristarain A, Bernardo RT, et al. A review of Antarctic surface snow isotopic composition: observations, atmospheric circulation, and isotopic modeling. J Clim. 2008;21(13):3359-87.

58. Thomas ER, van Wessem JM, Roberts J, Isaksson E, Schlosser E, Fudge TJ, Vallelonga P, Medley B, Lenaerts J, Bertler N, van den Broeke MR, Dixon DA, Frezzotti M, Stenni B, Curran M, Ekaykin AA. Review of regional Antarctic snow accumulation over the past 1000 years. Clim Past Discuss. 2017:1-42. https:// doi.org/10.5194/cp-2017-18.

59. Krinner G, Guicherd B, Ox K, Genthon C, Magand O. Influence of oceanic boundary conditions in simulations of Antarctic climate and surface mass balance change during the coming century. J Clim. 2008;21(5):938-62.

60. Scambos TA, Frezzotti M, Haran T, Bohlander J, Lenaerts JTM, Van Den Broeke MR, et al. Extent of low-accumulation "wind glaze" areas on the East Antarctic plateau: implications for continental ice mass balance. J Glaciol. 2012;58(210):633-47.

61. PAGES $2 \mathrm{k}$ Consortium. Continental-scale temperature variability during the past two millennia. Nat Geosci. 2013;6(5):339-46.

62. Magand O, Genthon C, Fily M, Krinner G, Picard G, Frezzotti M, et al. An up-to-date quality-controlled surface mass balance data set for the $90^{\circ}-180^{\circ} \mathrm{E}$ Antarctica sector and $1950-2005$ period. J Geophys Res. 2007;112(D12) https://doi.org/10.1029/ 2006JD007691.

63. Seo K-W, Wilson CR, Scambos T, Kim B-M, Waliser DE, Tian B, et al. Surface mass balance contributions to acceleration of Antarctic ice mass loss during 2003-2013. J Geophys Res Solid Earth. 2015;120(5):3617-27.

64. Zwally HJ, Li J, Robbins JW, Saba JL, Yi D, Brenner AC. Mass gains of the Antarctic ice sheet exceed losses. J Glaciol. 2015;61(230):1019-36.

65. Wang Y, Ding M, van Wessem JM, Schlosser E, Altnau S, van den Broeke MR, et al. A comparison of Antarctic Ice Sheet surface mass balance from atmospheric climate models and in situ observations. J Clim. 2016;29(14):5317-37.

66. Arthern RJ, Winebrenner DP, Vaughan DG. Antarctic snow accumulation mapped using polarization of $4.3-\mathrm{cm}$ wavelength microwave emission. J Geophys Res Atmospheres. 2006;111(D6):D06107.

67. Picard G, Domine F, Krinner G, Arnaud L, Lefebvre E. Inhibition of the positive snow-albedo feedback by precipitation in interior Antarctica. Nat Clim Chang. 2012;2(11):795-8.

68. Picard G, Brucker L, Fily M, Gallée H, Krinner G. Modeling time series of microwave brightness temperature in Antarctica. J Glaciol. 2009;55(191):537-51.

69. Trusel LD, Frey KE, Das SB. Antarctic surface melting dynamics: enhanced perspectives from radar scatterometer data. J Geophys Res. 2012;117(F2) https://doi.org/10.1029/2011JF002126.

70. Fujita S, Holmlund P, Andersson I, Brown I, Enomoto H, Fujii Y, et al. Spatial and temporal variability of snow accumulation rate on the East Antarctic ice divide between Dome Fuji and EPICA DML. Cryosphere. 2011;5(4):1057-81.

71. Verfaillie D, Fily M, Le Meur E, Magand O, Jourdain B, Arnaud $\mathrm{L}$, et al. Snow accumulation variability derived from radar and firn core data along a $600 \mathrm{~km}$ transect in Adelie Land, East Antarctic plateau. Cryosphere. 2012;6(6):1345-58.

72. Medley B, Joughin I, Smith BE, Das SB, Steig EJ, Conway H, et al. Constraining the recent mass balance of Pine Island and Thwaites glaciers, West Antarctica, with airborne observations of snow accumulation. Cryosphere. 2014;8(4):1375-92.
73. Medley B, Joughin I, Das SB, Steig EJ, Conway H, Gogineni S, et al. Airborne-radar and ice-core observations of annual snow accumulation over Thwaites Glacier, West Antarctica confirm the spatiotemporal variability of global and regional atmospheric models. Geophys Res Lett. 2013;40(14):3649-54.

74. Goursaud S, Masson-Delmotte V, Favier V, Preunkert S, Fily M, Gallée H, et al. A 60-year ice-core record of regional climate from Adélie Land, coastal Antarctica. Cryosphere. 2017;11(1):343-62.

75. Fraser AD, Nigro MA, Ligtenberg SRM, Legresy B, Inoue M, Cassano JJ, et al. Drivers of ASCAT C band backscatter variability in the dry snow zone of Antarctica. J Glaciol. 2016;62(231):170-84.

76. Briggs K, Shepherd A, Hogg A, Ivins E, Schlegel N, Joughin I, et al. Charting Ice Sheet Contributions to Global Sea Level Rise. Eos. 2016;97 https://doi.org/10.1029/2016EO055719.

77. Frezzotti M, Scarchilli C, Becagli S, Proposito M, Urbini S. A synthesis of the Antarctic surface mass balance during the last 800 yr. Cryosphere. 2013;7(1):303-19.

78. van Wessem JM, Reijmer CH, Morlighem M, Mouginot J, Rignot E, Medley B, et al. Improved representation of East Antarctic surface mass balance in a regional atmospheric climate model. J Glaciol. 2014;60(222):761-70.

79. Das I, Bell RE, Scambos TA, Wolovick M, Creyts TT, Studinger $\mathrm{M}$, et al. Influence of persistent wind scour on the surface mass balance of Antarctica. Nat Geosci. 2013;6(5):367-71.

80. Groot Zwaaftink CD, Cagnati A, Crepaz A, Fierz C, Macelloni G, Valt $\mathrm{M}$, et al. Event-driven deposition of snow on the Antarctic Plateau: analyzing field measurements with SNOWPACK. Cryosphere. 2013;7(1):333-47.

81. Das I, Scambos TA, Koenig LS, van den Broeke MR, Lenaerts JTM. Extreme wind-ice interaction over Recovery Ice Stream, East Antarctica: impact of winds on surface mass balance. Geophys Res Lett. 2015;42(19):8064-71.

82. Thiery W, Gorodetskaya IV, Bintanja R, Van Lipzig NPM, Van den Broeke MR, Reijmer CH, et al. Surface and snowdrift sublimation at Princess Elisabeth station, East Antarctica. Cryosphere. 2012;6(4):841-57.

83. Palerme C, Kay JE, Genthon C, L'Ecuyer T, Wood NB, Claud C. How much snow falls on the Antarctic ice sheet? Cryosphere. 2014;8(4):1577-87.

84. Behrangi A, Christensen M, Richardson M, Lebsock M, Stephens G, Huffman GJ, et al. Status of high-latitude precipitation estimates from observations and reanalyses. J Geophys Res Atmos. 2016;121(9):4468-86.

85. Gorodetskaya IV, Kneifel S, Maahn M, Thiery W, Schween JH, Mangold A, et al. Cloud and precipitation properties from groundbased remote-sensing instruments in East Antarctica. Cryosphere. 2015;9(1):285-304.

86. Grazioli J, Genthon C, Boudevillain B, Duran-Alarcon C, Del Guasta M, Madeleine J-B, et al. Measurements of precipitation in Dumont d'Urville, Terre Adélie, East Antarctica. Cryosphere. 2017;11:1797-811.

87. Palm SP, Yang Y, Spinhirne JD, Marshak A. Satellite remote sensing of blowing snow properties over Antarctica. J Geophys Res. 2011;116(D16) https://doi.org/10.1029/2011JD015828.

88. Palm SP, Kayetha V, Yang Y, Pauly R. Blowing snow sublimation and transport over Antarctica from 11 years of CALIPSO observations. Cryosphere Discuss. 2017:1-36. https://doi.org/10.5194/tc-2017-45.

89. Chritin V, Bolognesi R, Gubler H. FlowCapt: a new acoustic sensor to measure snowdrift and wind velocity for avalanche forecasting. Cold Reg Sci Technol. 1999;30(1):125-33.

90. Cierco F-X, Naaim-Bouvet F, Bellot H. Acoustic sensors for snowdrift measurements: how should they be used for research purposes? Cold Reg Sci Technol. 2007;49(1):74-87.

91. Scarchilli C, Frezzotti M, Grigioni P, De Silvestri L, Agnoletto L, Dolci S. Extraordinary blowing snow transport events in East Antarctica. Clim Dyn. 2010;34(7-8):1195-206. 
92. Lenaerts JTM, van den Broeke MR, Déry SJ, van Meijgaard E, van de Berg WJ, Palm SP, Sanz Rodrigo J. Modeling drifting snow in Antarctica with a regional climate model: 1. Methods and model evaluation, 1. J Geophys Res Atmos. 2012;117(D5). https://doi.org/10.1029/2011JD016145.

93. Sato T, Kimura T, Ishimaru T, Maruyama T. Field test of a new snow-particle counter (SPC) system. Ann Glaciol. 1993;18(1): 149-54.

94. Trouvilliez A, Naaim-Bouvet F, Bellot H, Genthon C, Gallée H. Evaluation of the FlowCapt acoustic sensor for the aeolian transport of snow. J Atmos Ocean Technol. 2015;32(9):1630-41.

95. Trouvilliez A, Naaim-Bouvet F, Genthon C, Piard L, Favier V, Bellot $\mathrm{H}$, et al. A novel experimental study of aeolian snow transport in Adelie Land (Antarctica). Cold Reg Sci Technol. 2014;108:125-38.

96. van de Berg WJ, van den Broeke MR, Reijmer CH, van Meijgaard E (2006) Reassessment of the Antarctic surface mass balance using calibrated output of a regional atmospheric climate model. J Geophys Res 111(D11). doi:https://doi.org/10.1029/2005JD006495.

97. van Wessem JM, Ligtenberg SRM, Reijmer $\mathrm{CH}$, van de Berg WJ, van den Broeke MR, Barrand NE, et al. The modelled surface mass balance of the Antarctic Peninsula at $5.5 \mathrm{~km}$ horizontal resolution. Cryosphere. 2016;10(1):271-85.

98. van Wessem JM, Reijmer CH, Lenaerts JTM, van de Berg WJ, van den Broeke MR, van Meijgaard E. Updated cloud physics in a regional atmospheric climate model improves the modelled surface energy balance of Antarctica. Cryosphere. 2014;8(1):125-35.

99. Lenaerts JTM, van den Broeke MR. Modeling drifting snow in Antarctica with a regional climate model: 2. Results. J Geophys Res Atmos. 2012;117(D5). https://doi.org/10.1029/2010JD015419.

100. Amory C, Trouvilliez A, Gallée H, Favier V, Naaim-Bouvet F, Genthon $\mathrm{C}$, et al. Comparison between observed and simulated aeolian snow mass fluxes in Adélie Land, East Antarctica. Cryosphere. 2015;9(4):1373-83.

101. Barral H, Genthon C, Trouvilliez A, Brun C, Amory C. Blowing snow in coastal Adélie Land, Antarctica: three atmosphericmoisture issues. Cryosphere. 2014;8(5):1905-19.

102. Lenaerts JTM, Smeets CJPP, Nishimura K, Eijkelboom M, Boot $\mathrm{W}$, van den Broeke MR, et al. Drifting snow measurements on the Greenland Ice Sheet and their application for model evaluation. Cryosphere. 2014;8(2):801-14.

103. Gallée H, Trouvilliez A, Agosta C, Genthon C, Favier V, NaaimBouvet F. Transport of snow by the wind: a comparison between observations in Adélie Land, Antarctica, and simulations made with the Regional Climate Model MAR. Bound-Layer Meteorol. 2013;146(1):133-47.

104. Vignon E, Genthon C, Barral H, Amory C, Picard G, Gallée H, et al. Momentum- and heat-flux parametrization at Dome C, Antarctica: a sensitivity study. Bound-Layer Meteorol. 2017;162(2):341-67.

105. Amory C, Naaim-Bouvet F, Gallée H, Vignon E. Brief communication: two well-marked cases of aerodynamic adjustment of sastrugi. Cryosphere. 2016;10(2):743-50.

106. Amory C, Gallée H, Naaim-Bouvet F, Favier V, Vignon E, Picard G, Trouvilliez A, Piard L, Genthon C, Bellot H. Seasonal variations in drag coefficients over a sastrugi-covered snowfield of coastal East Antarctica. Bound-Layer Meteorol. 2017;164(1):107-33.

107. Libois Q, Picard G, Arnaud L, Morin S, Brun E. Modeling the impact of snow drift on the decameter-scale variability of snow properties on the Antarctic Plateau. J Geophys Res Atmos. 2014;119(20):11,662-81.

108. King JC, Gadian A, Kirchgaessner A, Kuipers Munneke P, Lachlan-Cope TA, Orr A, et al. Validation of the summertime surface energy budget of Larsen C Ice Shelf (Antarctica) as represented in three high-resolution atmospheric models. J Geophys Res Atmos. 2015;120(4):1335-47.
109. Ligtenberg SRM, Kuipers Munneke P, van den Broeke MR. Present and future variations in Antarctic firn air content. Cryosphere. 2014;8(5):1711-23.

110. Hubbard B, Luckman A, Ashmore DW, Bevan S, Kulessa B, Kuipers Munneke P, et al. Massive subsurface ice formed by refreezing of ice-shelf melt ponds. Nat Commun. 2016;7:11897.

111. Kuipers Munneke P, Ligtenberg SRM, Van Den Broeke MR, Vaughan DG. Firn air depletion as a precursor of Antarctic iceshelf collapse. J Glaciol. 2014;60(220):205-14.

112. Kuipers Munneke P, Ligtenberg SRM, Suder EA, Van Den Broeke MR. A model study of the response of dry and wet firn to climate change. Ann Glaciol. 2015;56(70):1-8.

113. Cape MR, Vernet M, Skvarca P, Marinsek S, Scambos T, Domack E. Foehn winds link climate-driven warming to ice shelf evolution in Antarctica. J Geophys Res Atmos. 2015;120(21):11,037-57.

114. Luckman A, Elvidge A, Jansen D, Kulessa B, Kuipers Munneke P, King J, et al. Surface melt and ponding on Larsen C Ice Shelf and the impact of föhn winds. Antarct Sci. 2014;26(06):625-35.

115. Lenaerts JTM, Lhermitte S, Drews R, Ligtenberg SRM, Berger S, Helm V, et al. Meltwater produced by wind-albedo interaction stored in an East Antarctic ice shelf. Nat Clim Chang. 2016;7(1):58-62.

116. Thomas ER, Bracegirdle TJ, Turner J, Wolff EW. A 308 year record of climate variability in West Antarctica. Geophys Res Lett. 2013;40(20):5492-6.

117. Philippe M, Tison J-L, Fjøsne K, Hubbard B, Kjær HA, Lenaerts JTM, et al. Ice core evidence for a 20th century increase in surface mass balance in coastal Dronning Maud Land, East Antarctica. Cryosphere. 2016;10(5):2501-16.

118. Thomas ER, Marshall GJ, McConnell JR. A doubling in snow accumulation in the western Antarctic Peninsula since 1850. Geophys Res Lett. 2008;35(1) https://doi.org/10.1029/ 2007GL032529.

119. Peel AD. Spatial temperature and accumulation rate variations at the Antarctic Peninsula. In: Morris EM, editor. The contribution of Antarctic Peninsula ice to sea level rise. Cambridge: British Antarctic Survey; 1992. p. 11-5.

120. Lenaerts JTM, van Meijgaard E, van den Broeke MR, Ligtenberg SRM, Horwath M, Isaksson E. Recent snowfall anomalies in Dronning Maud Land, East Antarctica, in a historical and future climate perspective. Geophys Res Lett. 2013;40(11):2684-8.

121. Previdi M, Polvani LM. Impact of the Montreal Protocol on Antarctic surface mass balance and implications for global sea level rise. J Clim. 2017;30(18):7247-53.

122. Turner J, Bracegirdle TJ, Phillips T, Marshall GJ, Hosking JS. An initial assessment of Antarctic sea ice extent in the CMIP5 models. J Clim. 2013;26(5):1473-84.

123. Manabe S, Stouffer RJ. Sensitivity of a global climate model to an increase of $\mathrm{CO}_{2}$ concentration in the atmosphere. J Geophys Res. 1980;85(C10):5529-54.

124. Hansen J, Fung I, Lacis A, Rind D, Lebedeff S, Ruedy R, et al. Global climate changes as forecast by Goddard Institute for Space Studies three-dimensional model. J Geophys Res Atmos. 1988;93(D8):9341-64.

125. Flato G, Marotzke J, Abiodun B, Braconnot P, Chou SC, Collins W, et al. Evaluation of climate models. Climate Change 2013: the physical science basis. In: Stocker TF, Qin D, Plattner G-K, Tignor M, Allen SK, Boschung J, Nauels A, Xia Y, Bex V, Midgley PM, editors. Contribution of Working Group I to the Fifth Assessment Report of the Intergovernmental Panel on Climate Change. Cambridge: Cambridge University Press; 2013.

126. Pattyn F, Favier L, Sun S, Durand G. Progress in numerical modeling of antarctic ice-sheet dynamics. Curr Clim Change Rep. 2017;3(3):174-84.

127. Powers JG, Manning KW, Bromwich DH, Cassano JJ, Cayette AM. A decade of Antarctic science support through Amps. Bull Am Meteorol Soc. 2012;93(11):1699-712. 
128. Fréville H, Brun E, Picard G, Tatarinova N, Arnaud L, Lanconelli $\mathrm{C}$, et al. Using MODIS land surface temperatures and the Crocus snow model to understand the warm bias of ERA-Interim reanalyses at the surface in Antarctica. Cryosphere. 2014;8(4): 1361-73.

129. Kingslake J, Ely JC, Das I, Bell RE. Widespread movement of meltwater onto and across Antarctic ice shelves. Nature. 2017;544(7650):349-52.

130. Bromwich DH, Nicolas JP, Hines KM, Kay JE, Key EL, Lazzara MA, et al. Tropospheric clouds in Antarctica. Rev Geophys. 2012;50(1) https://doi.org/10.1029/2011RG000363.

131. Lenaerts JTM, Van Tricht K, Lhermitte S, L'Ecuyer TS. Polar clouds and radiation in satellite observations, reanalyses, and climate models. Geophys Res Lett. 2017;44(7):3355-64.

132. Gallée H, Preunkert S, Argentini S, Frey MM, Genthon C, Jourdain B, et al. Characterization of the boundary layer at Dome C (East Antarctica) during the OPALE summer campaign. Atmos Chem Phys. 2015;15(11):6225-36.

133. Genthon C, Six D, Scarchilli C, Ciardini V, Frezzotti M. Meteorological and snow accumulation gradients across Dome C, East Antarctic plateau. Int J Climatol. 2016;36(1):455-66.

134. Hall A. Projecting regional change. Science. 2014;346(6216): 1461-2.

135. Giorgi F, Gutowski WJ. Coordinated experiments for projections of regional climate change. Curr Clim Chang Rep. 2016;2(4):20210.

136. Gutowski WJ, Giorgi F, Timbal B, Frigon A, Jacob D, Kang H-S, et al. WCRP COordinated Regional Downscaling EXperiment
(CORDEX): a diagnostic MIP for CMIP6. Geosci Model Dev. 2016;9(11):4087-95.

137. Agosta C, Fettweis X, Datta R. Evaluation of the CMIP5 models in the aim of regional modelling of the Antarctic surface mass balance. Cryosphere. 2015;9(6):2311-21.

138. Ashfaq M, Skinner CB, Diffenbaugh NS. Influence of SST biases on future climate change projections. Clim Dyn. 2011;36(7-8): 1303-19.

139. Guldberg A, Kaas E, Déqué M, Yang S, Vester Thorsen S. Reduction of systematic errors by empirical model correction: impact on seasonal prediction skill. Tellus Dyn Meteorol Oceanogr. 2005;57(4):575-88.

140. Kharin VV, Scinocca JF. The impact of model fidelity on seasonal predictive skill. Geophys Res Lett. 2012;39(18) https://doi.org/10. 1029/2012GL052815.

141. Nicolas JP, Vogelmann AM, Scott RC, Wilson AB, Cadeddu MP, Bromwich DH, et al. January 2016 extensive summer melt in West Antarctica favoured by strong El Niño. Nat Commun. 2017;8: 15799.

142. Sallée JB, Speer K, Morrow R. Response of the Antarctic Circumpolar Current to atmospheric variability. J Clim. 2008;21(12):3020-39.

143. Cai W, Borlace S, Lengaigne M, van Rensch P, Collins M, Vecchi $\mathrm{G}$, et al. Increasing frequency of extreme El Niño events due to greenhouse warming. Nat Clim Chang. 2014;4(2):111-6.

144. Wang G, Cai W, Gan B, Wu L, Santoso A, Lin X, et al. Continued increase of extreme El Niño frequency long after $1.5^{\circ} \mathrm{C}$ warming stabilization. Nat Clim Chang. 2017;7(8):568-72. 